\title{
Nitromethane K-9 Detection Limit
}

\author{
R. Strobel, J. Kury
}

August 29, 2003

U.S. Department of Energy

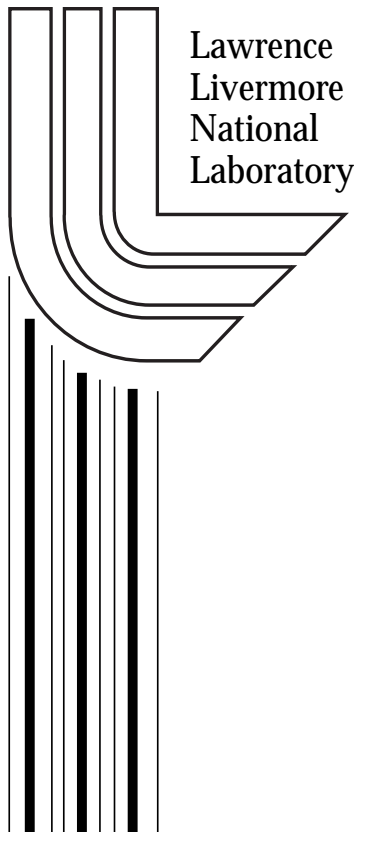




\section{DISCLAIMER}

This document was prepared as an account of work sponsored by an agency of the United States Government. Neither the United States Government nor the University of California nor any of their employees, makes any warranty, express or implied, or assumes any legal liability or responsibility for the accuracy, completeness, or usefulness of any information, apparatus, product, or process disclosed, or represents that its use would not infringe privately owned rights. Reference herein to any specific commercial product, process, or service by trade name, trademark, manufacturer, or otherwise, does not necessarily constitute or imply its endorsement, recommendation, or favoring by the United States Government or the University of California. The views and opinions of authors expressed herein do not necessarily state or reflect those of the United States Government or the University of California, and shall not be used for advertising or product endorsement purposes.

This work was performed under the auspices of the U. S. Department of Energy by the University of California, Lawrence Livermore National Laboratory under Contract No. W-7405-Eng-48.

This report has been reproduced directly from the best available copy.

Available electronically at http://www.doc.gov/bridge

Available for a processing fee to U.S. Department of Energy

And its contractors in paper from

U.S. Department of Energy

Office of Scientific and Technical Information

P.O. Box 62

Oak Ridge, TN 37831-0062

Telephone: (865) 576-8401

Facsimile: (865) 576-5728

E-mail: reports@adonis.osti.gov

Available for the sale to the public from

U.S. Department of Commerce

National Technical Information Service

5285 Port Royal Road

Springfield, VA 22161

Telephone: (800) 553-6847

Facsimile: (703) 605-6900

E-mail: orders@ntis.fedworld.gov

Online ordering: http://www.ntis.gov/ordering.htm

OR

Lawrence Livermore National Laboratory

Technical Information Department's Digital Library

http://www.llnl.gov/tid/Library.html 


\title{
Nitromethane K-9 Detection Limit
}

\author{
Richard Strobel \\ Bureau of Alcohol, Tobacco and Firearms \\ John Kury \\ Lawrence Livermore National Laboratory
}

\section{Introduction}

The Bureau of Alcohol, Tobacco and Firearms (ATF) trains canine/handler teams to detect explosives for government and other agencies worldwide. After completing the training program the teams are tested on an array containing explosives and numerous other samples designed to distract a canine. Passing this test results in a team's certification.

These teams can be considered as 'detection instruments' freshly calibrated just before leaving the 'factory'. Using these teams to examine special experimental arrays immediately following certification can lead to a better understanding of a canine's detection capabilities.

Forty-one of these 'detection instruments' were used in four test series with arrays containing dilute nitromethane-in-water solutions. (The canines had been trained on the amount of nitromethane vapor in equilibrium with the undiluted liquid explosive.) By diluting liquid nitromethane with water, the amount of explosive vapor can be reduced many orders of magnitude to test the lower limit of the canine's nitromethane vapor detection response. The results are presented in this paper.

\section{$\underline{\text { Test Description }}$}

Most samples were placed in the standard ATF test wheel geometry show in Figure 1. Two-ounce ointment tins with holes punched in the lids contained either diluted nitromethane, actual explosives or distracters. A number of empty tins were also used in the array. The tins were placed in quart cans that were then placed inside gallon cans attached to the wheel.

Individual gallon cans positioned in a linear array were used for one series of tests. On two series of tests several individual gallon cans containing samples were positioned after the last wheel in the array.

Series I with 12 canine/handler teams was run on September 18, 2000 using eight wheels. Twenty-

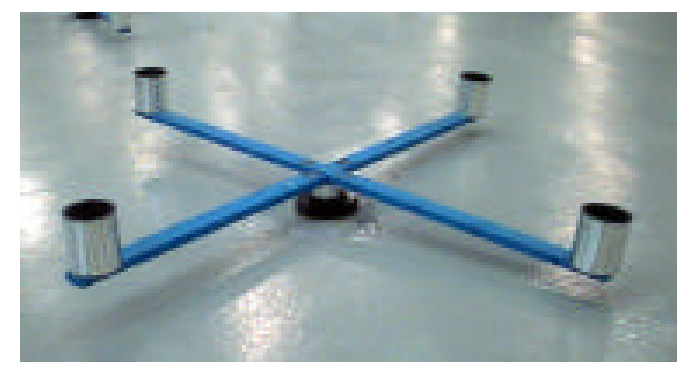

Figure 1. ATF test wheel four tins were empty and 8 contained nitromethane diluted with de-ionized water. The tins' lids had 15 holes $\sim 1.5 \mathrm{~mm}$ in diameter.

Series II with 12 canine/handler teams was run on November 27, 2000 using a linear array of 40 cans. Seven tins were empty. Six tins contained distilled water. Six tins contained distracters and 6 tins contained explosives. Fifteen tins contained nitromethane diluted with distilled water. The tins' lids had 13 holes $\sim 1.0 \mathrm{~mm}$ in diameter. 
Five canine/handler teams were used in Series III screening experiments on March 7, 2001. Four wheels and 2 individual cans were used. Three tins contained tap water and 1 tin contained a distracter. Six tins contained explosive and 8 tins contained nitromethane diluted with tap water. The tins' lids had 13 holes $\sim 1.0 \mathrm{~mm}$ in diameter.

Series IV with 12 canine/handler teams was run on May 8, 2001 using seven wheels and three individual cans. Eight tins were empty and 6 contained tap water. Four contained explosives and 13 contained nitromethane diluted with tap water. The tins' lids had 15 holes $\sim 1.0 \mathrm{~mm}$ in diameter.

The standard ATF scoring procedure was used to record the canine's response. Teams were allowed to circle a wheel twice at the handler's discretion. Sitting indicated a positive reaction to the sample. On correctly identifying an explosive or nitromethane-containing sample the canine was give a food reward.

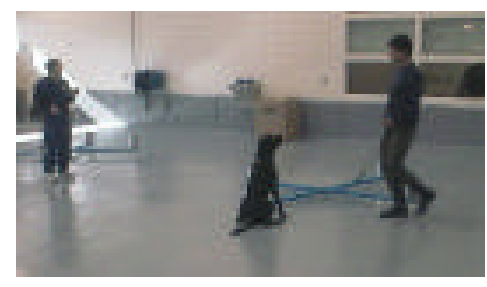

\section{Test Results}

Figure 2. Positive

There were 503 tests of nitromethane and diluted nitromethane samples. The results are presented in Table 1. (Scorer sheets are summarized in Appendix A.)

Table 1. Detection results for water-diluted nitromethane solutions

\begin{tabular}{|c|c|c|c|}
\hline $\begin{array}{c}\text { Nitromethane Vapor } \\
\text { Pressure Range (microns) } \\
\end{array}$ & $\begin{array}{l}\text { Number of Dog/ } \\
\text { Handler Teams } \\
\end{array}$ & $\begin{array}{l}\text { Total } \\
\text { Tests } \\
\end{array}$ & $\begin{array}{c}\text { Total Positive } \\
\text { Responses } \\
\end{array}$ \\
\hline $4 \times 10^{4}$ (pure nitromethane) & 12 on $5 / 8 / 01$ tests & 17 & $16(94 \%)$ \\
\hline $1 \times 10^{3}$ to $1 \times 10^{2}$ & $\begin{array}{l}12 \text { on } 9 / 18 / 00 \text { tests } \\
12 \text { on } 11 / 27 / 00 \text { tests }\end{array}$ & 44 & $40(91 \%)$ \\
\hline to $3 \times 10^{0}$ & $\begin{array}{l}12 \text { on } 9 / 18 / 00 \text { tests } \\
12 \text { on } 11 / 27 / 00 \text { tests }\end{array}$ & 36 & $26(72 \%)$ \\
\hline to $1 \times 10^{-2}$ & $\begin{array}{l}12 \text { on } 9 / 18 / 00 \text { tests } \\
12 \text { on } 11 / 27 / 00 \text { tests }\end{array}$ & 48 & $41(85 \%)$ \\
\hline to $1 \times 10^{-4}$ & $\begin{array}{l}12 \text { on } 9 / 18 / 00 \text { tests } \\
12 \text { on } 11 / 27 / 00 \text { tests }\end{array}$ & 42 & $37(88 \%)$ \\
\hline to $1 \times 10^{-6}$ & $\begin{array}{c}12 \text { on } 11 / 27 / 00 \text { tests } \\
5 \text { on } 3 / 7 / 01 \text { tests }\end{array}$ & 79 & $68(86 \%)$ \\
\hline $3 \times 10^{-7} \quad$ to $\quad 1 \times 10^{-8}$ & $\begin{array}{c}5 \text { on } 3 / 7 / 01 \text { tests } \\
12 \text { on } 5 / 8 / 01 \text { tests }\end{array}$ & 96 & $44(46 \%)$ \\
\hline $3 \times 10^{-9}$ to $1 \times 10^{-9}$ & $\begin{array}{c}5 \text { on } 3 / 7 / 01 \text { tests } \\
12 \text { on } 5 / 8 / 01 \text { tests }\end{array}$ & 41 & $28(68 \%)$ \\
\hline to $3 \times 10^{-13}$ & 12 on $5 / 8 / 01$ tests & 68 & $44(65 \%)$ \\
\hline
\end{tabular}

\section{Observations}

Some of the most significant knowledge gained in these series of experiments centered on the unique difficulties in the testing of detection canines. Among the observations:

- Canines are at all times thinking, learning creatures. It is difficult to design the "learning factor" out of a test protocol.

- The canine must be trained and familiar in the test methodology; the mechanics of the test. 
- The levels of the substance to be detected experimentally must also be included in the canines normal training. A dog not trained to detect very low levels may not do so in an experiment. The dog must be trained at the levels it will be expected to work.

- The presentation order of low levels of a target substance affects the test results. If a relatively high level of a target odor is presented first on a wheel together with a low level of the same substance the dog may selectively alert to the higher level only.

\section{Conclusion}

The probability of detecting nitromethane remained high until the vapor pressure fell below $\sim 1 \times 10^{-6}$ microns. This would place detection limits in the parts-per-trillion range in the headspace above the sample tin. There are indications that some of the canines were detecting much lower concentrations of nitromethane vapor, but the evidence from these experiments is inconclusive. Further work lies ahead. 